UDK/UDC: 504.4:551.578.48(497.4)

Prejeto/Received: 11.02 .2021

Pregledni znanstveni članek - Review scientific paper

Sprejeto/Accepted: 09.04.2021

DOI: $10.15292 /$ acta.hydro.2021.04

Objavljeno na spletu/Published online: 02.06.2021

\title{
After 2000 Stože LandSlide: PART II - DeVelopMent In landSLIDE Disaster RISK REDUCTION POLICY IN SLOVENIA
}

\section{PO ZEMELJSKEM PlaZu STOŽE LETA 2000: Del II - RAZVOJ POLITIKE ZMANJŠEVANJA TVEGANJA NESREČ ZARADI ZEMELJSKIH PLAZOV V SLOVENIJI \\ MATJAŽ Mikoš ${ }^{1}$}

${ }^{1}$ Raziskovalni inštitut za geo in hidro tveganja, Fakulteta za gradbeništvo in geodezijo, Univerza v Ljubljani, Jamova c. 2, 1000 Ljubljana, E-pošta: matjaz.mikos@fgg.uni-lj.si

\begin{abstract}
More than 20 years after the 2000 Stože Landslide that devastated the village of Log pod Mangartom in NW Slovenia, this paper gives a review of the short-term response to and disaster relief provided for this catastrophic event, and further summarises this event's effects on Slovenia's efforts to improve its system of preventing natural disasters caused by various forms of landslides. Recent advances in reducing landslide disasters in Slovenia after 2000 are presented, including hazard and risk maps for landslides, rockfalls, and debris flows based on modern methodologies. Also, a short overview is given of Slovenian international cooperation on natural disasters. The developments in the landslide disaster risk reduction policy have unfortunately been less obvious in terms of the state taking preventive measures by adopting relevant legislation for adequate spatial planning.
\end{abstract}

Keywords: debris flows, hazards, landslides, legislation, natural disasters, risks, Slovenia, Stože landslide.

\section{Izvleček}

Po več kot 20 letih od plazu Stože leta 2000, ki je opustošil vas Log pod Mangartom v SZ Sloveniji, ta članek podaja pregled kratkoročnega odziva in pomoči ob nesreči ter nadalje povzema vpliv tega dogodka na prizadevanja v Republiki Sloveniji za izboljšanje sistema za preprečevanje naravnih nesreč, ki jih povzročajo različne oblike zemeljskih plazov. Predstavljen je nedavni napredek na področju zmanjševanja nevarnosti delovanja zemeljskih plazov v Sloveniji po letu 2000, vključno s kartami nevarnosti in ogroženosti za zemeljske plazove, skalne podore in drobirske tokove, ki so bile izdelane na podlagi sodobnih metodologij. Podan je tudi kratek pregled mednarodnega sodelovanja Slovenije na področju naravnih nesreč. Razvoj politike zmanjševanja naravnih in drugih nesreč zaradi delovanja zemeljskih plazov je bil žal manj očiten na področju preventivnih ukrepov države, ki bi s sprejetjem ustreznih zakonskih aktov okrepila preventivno delovanje $\mathrm{z}$ njihovo uporabo $\mathrm{v}$ ustreznih postopkih prostorskega načrtovanja.

Ključne besede: drobirski tok, naravne nesreče, nevarnosti, Slovenija, tveganja, zakonodaja, zemeljski plaz Stože, zemeljski plazovi.

\footnotetext{
${ }^{1}$ Stik/Correspondence: matjaz.mikos@fgg.uni-lj.si

(C) Mikoš M.; Vsebina tega članka se sme uporabljati v skladu s pogoji licence Creative Commons Priznanje avtorstva - Nekomercialno - Deljenje pod enakimi pogoji 4.0 .

(C) Mikoš M.; This is an open-access article distributed under the terms of the Creative Commons Attribution - NonCommercial ShareAlike 4.0 Licence.
} 


\section{Introduction}

The 2000 Stože Landslide, along with its consequent debris flow that devastated the village of Log pod Mangartom and claimed 7 casualties, was the largest natural disaster of this kind in the 20th century in Slovenia. Its impact on landslide research in Slovenia thereafter was the focus of the companion paper (Mikoš, 2020d). The current paper, interested in the development of landslide risk reduction policy in Slovenia thereafter, deals rather with the question: "What lessons have been learned from this event?"

Landslides, as a general term for various types of slope mass movements (Varnes et al., 2014), are frequent but localised natural events causing significant human and economic loss around the world (Fig. 1). Froude and Petley (2018) presented a spatiotemporal analysis of a global dataset of fatal non-seismic landslides, covering the period from January 2004 to December 2016. The data show that in total 55,997 people were killed in 4862 distinct landslide events. Haque et al. (2016) presented a spatio-temporal distribution of deadly landslides for 27 European countries over the 20 years (19952014). Catastrophic landslides occur in broad distribution throughout Europe, though with a greater concentration in mountainous areas (i.e. including the Alps). In the studied period, a total of 1370 deaths and 784 injuries were reported, resulting from 476 landslides. Slovenia was recognised as a consecutive hot spot, but without a significant trend (Haque et al., 2016, Fig. 7). The authors also stated that fatal landslides are mostly triggered by natural extreme events such as heavy rainfalls, earthquakes, and floods, and only minor ones by human activities such as mining and excavation works.

Not all landslides are fatal, and it is important to investigate all different forms of landslides, and the best way to do that is to establish a landslide cadastre (database). Herrera et al. (2018) analysed landslide databases from 27 Geological Surveys of Europe, including that of Slovenia with 849,543 landslide records, from which $36 \%$ are slides, $10 \%$ are falls, $20 \%$ are flows, $11 \%$ are complex slides, and $24 \%$ either remain unclassified or correspond to another typology. The Slovenian database records 7,273 landslides, nearly all of which were slides $(7,264)$, along with 8 falls and 1 flow (Herrera et al., 2018). According to this analysis, over $80 \%$ of Slovenian municipalities are affected by landslides, and the landslide density is $\sim 0.4$ landslide $/ \mathrm{km}^{2}$ (Herrera et al., 2018).

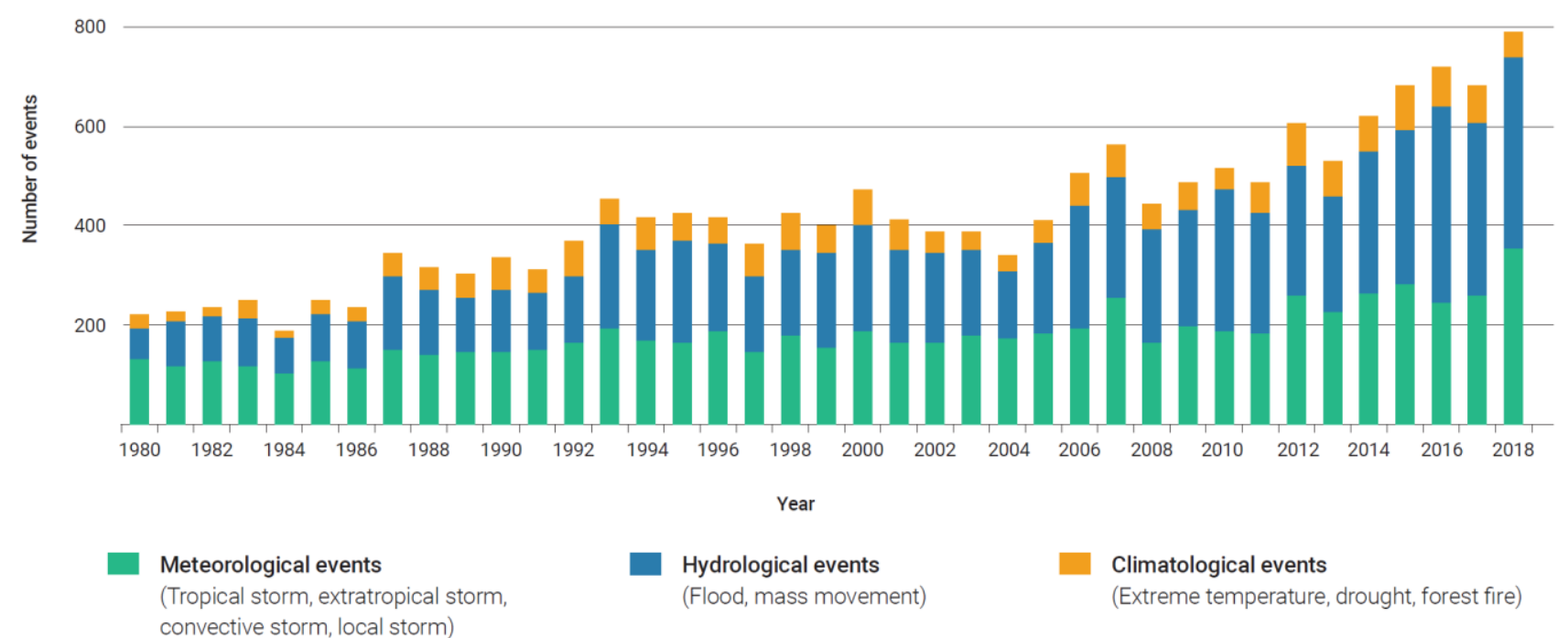

Figure 1: World weather-related natural catastrophes by peril, 1980-2018 (Fig. 15 from WWDR, 2020; p. 23) that have caused at least one fatality.

Slika 1: Naravne katastrofe v svetu zaradi vremenskih ujm, 1980-2018 (slika 15 iz WWDR, 2020; str. 23), ki so zahtevale najmanj eno smrtno žrtev. 
Komac and Hribernik (2015) reported 6,234 landslides for Slovenia in 2014; much less than the 7,000 to 10,000 landslides estimated by Ribičič et al. (1994).

After the data from the Statistical Office of the Republic of Slovenia on damages caused by natural disasters, landslides were to be blamed for damages amounting to over 100 million EUR between 1991 and 2008 (Zorn and Hrvatin, 2015).

Awareness about landslide risks in Slovenia did not start with 2000 Stože Landslide; several professional associations had been active in researching landslides in the past, e.g. since 1951 the Slovenian Geological Society (SGD; https://www.slovenskogeoloskodrustvo.si/), since 1951 the Slovenian Union of Civil Engineers and Technicians (ZDGITS; www.zveza-dgits.si), and since 1985 its Geotechnical Section, and since 1992 the Slovenian Geotechnical Society (SloGeD; http://sloged.si/). Before the 2000 Stože event, three symposia on landslides in Slovenia were held: 1994 in Idrija (Režun et al., 1994), 1996 in Šmarje pri Jelšah (Cvek, 1999), and 1999 at Rogla (Anonymous, 1999). A university textbook on water-related disasters was written by Brilly et al. (1999), with a short section on landslides, including debris flows.

An excellent overview of landslide research and disaster risk reduction policy before 2008 was given by Zorn and Komac (2008) in a monograph on landslides in Slovenia. A geological overview on landslide research was also produced by Komac (2017) and Jemec Auflič et al. (2018a). Legislation and procedures for assessing hazards and risks related to landslides, rockfalls, and debris flows in Slovenia were studied by Mikoš et al. (2014). The latest, modern overview on landslide disaster risk reduction in Slovenia was made by Mikoš et al. (2018).

The 2000 Stože Landslide raised awareness and established a new public perception about fastflowing debris flows that were thitherto infrequent in Slovenia.

As modern joint international efforts for global landslide disaster risk reduction policies are strengthening (e.g. Sassa, 2015; 2019), especially under the Sendai Framework for Disaster Risk Reduction 2015-2030 and its 7 targets and 4 priorities for action (UNISDR, 2015), this policy also considers the impact of climate change on landslides (Gariano and Guzzetti, 2016), an overview of the development of such a policy in Slovenia after 2000 Stože Landslide is given in this paper. As more details on the 2000 Stože Landslide event are given in the companion paper (Mikoš, 2020d), we will start the overview with how responses and relief to natural disasters are organised in Slovenia.

\section{Development of landslide disaster risk reduction in Slovenia after the $\mathbf{2 0 0 0}$ Stože Landslide}

In this chapter, no description of the 2000 Stože Landslide disaster dynamics and its triggering factors is given, though a short review is given in Mikoš (2020d).

\subsection{Immediate response and disaster relief after the 2000 Stože Landslide}

Disaster management in Slovenia is organised as an integrated system including several parties: rescue units and services (professional and voluntary, civil protection), humanitarian organisations, research institutions, other organisations, and governmental administrative bodies. The unified system is based on humanitarian principles and is in line with international standards. The system is regulated by the Act on Protection against Natural and Other Disasters (ZVNDN-B, 2010) and other sectorspecific acts. It addresses all phases of the cycle: prevention, preparedness, response to disasters (protection, rescue and relief), and recovery (Factsheet: https://ec.europa.eu/echo/what/civilprotection/disaster-management/slovenia en).

The responsibilities for the disaster management system lie with the government, local communities, commercial companies, and citizens. The system is based on a bottom-up approach and systematic (subsidiary) principle. The national authority responsible for disaster management is the 
Administration of the Republic of Slovenia for Civil Protection and Disaster Relief (ACPDR; www.sos112.si Slov. Uprava Republike Slovenije za zaščito in reševanje) within the Ministry of Defence. When needed, the Slovenian Police and Slovenian Armed Forces are activated to exercise disaster relief activities as well.

Funds for disaster response are normally granted from the Reserve Fund of the Government of the Republic of Slovenia.

In the second phase after the landslide event, recovery efforts are headed by the Division for Rehabilitation after Natural and Other Disasters (Slov. Sektor za zmanjševanje posledic naravnih nesreč), which is a part of the Water and Investments Directorate of the Ministry of the Environment and Spatial Planing (Slov. Direktorat za vode in investicije Ministrstva za okolje in prostor). These funds are allocated, as a rule, through the adoption of a special act on rehabilitation.

For the case of the 2000 Stože Landslide catastrophic event in NW Slovenia, its immediate short-term consequences can be summarised as follows:

- The immediate response to the disaster and disaster relief in Log pod Mangartom fell under the auspices of the municipal (local) and regional civil protection units, with the main contribution from fire brigade members, who were overwhelmed by the severity of the disaster since they had no such pertinent experience. This fact stresses the importance of providing adequate practical training to civil protection units in order to increase their capacity for coping with such large-scale natural disasters. Their efforts were therefore supported by some volunteers and ad-hoc committees, later accepted by the disaster response management system in the devastated area as officially nominated experts on geology, geotechnical and hydraulic engineering, and torrent control, as well as selected national research institutions with expertise in hydrology, geological engineering, remote sensing, and civil engineering (Ušeničnik, 2001).

- A very detailed analysis of crisis management and communicating risks to the local population and general public for the 2000 Stože Landslide was made by Krajnc (2004). He was critical about the disharmony among various experts on how to lead immediate remediation measures, and about the dispute that broke out between experts and the official crisis management bodies.

- The disaster temporarily raised awareness about catastrophic natural events among the general public, which reacted to the event by raising substantial funds to help the local population of the village Log pod Mangartom.

- The disaster clearly showed that there was a lack of clear delegation of responsibility between the Ministry of Defence, in charge for immediate response and disaster relief, and the Ministry of the Environment and Spatial Planning, in charge for preventing natural hazards (disaster risk reduction) and the longterm remediation of devastated areas.

- The first phase during and immediately after the disaster in November and December 2000 (relief intervention of emergency units especially those for civil protection) can be described as concern-driven crisis management or as judgment-based crisis management, respectively (Mikoš, 2011a). The quantitative risk assessment came into play in the second remediation phase through special law enforcement.

- Recently, Malešič (2020) made an analysis of the Slovenian disaster response from a comparative perspective, using several disasters that happened after the 2000 Stože Landslide (wildfires, hail storms, the 2007 Železniki flood, the 2014glaze ice). The response to the aforementioned disasters was not universal; on the contrary, crisis management actors demonstrated various modes of response. Formally, the response structure was centralized and hierarchical; however, in 
practice there were many activities that bypassed or even ignored formal procedures. Some actors even functioned outside the planned response framework (humanitarian organizations, and volunteers). This analysis shows that the Slovenian Disaster Response Management System needs further refinement.

- As far as disaster response in Slovenia is concerned, the system envisages that a commander of the affected area's Civil Protection coordinates the activities of all involved organizations; but concurrently, they have the possibility to appoint an incident commander to perform operational tasks related to disaster response (Malešič, 2020). Also, in the case of the 2000 Stože Landslide disaster, an incident commander was in charge, but was soon removed due to health problems, and was replaced by the Commander of the Civil Protection (Ušeničnik, 2001).

- The Slovenian Parliament immediately adopted a special act to secure funds for the extensive, long-term remediation of the devastated area in Log pod Mangartom (ZUPSB, 2000). This was been upgraded to a new act in 2002, covering in total the mitigation of six large-scale landslides in Slovenia (ZUOPZP, 2002), including the Stože Landslide. This act was amended a few times in the years to come (in 2005 and 2012), and the area's remediation is still not finished, since a few infrastructural objects (such as local footbridges) must be built.

- Slovenia's government adopted a special decree (Uredba, 2004), with provisions that included production of a debris-flow risk map of Log pod Mangartom, as well as the definition of risk classes and conditions and restrictions for rehabilitation and construction activities in the risk area. This was the first time in Slovenia that the Water Act (2002) was applied in defining a risk area anywhere in Slovenia (Mikoš et al., 2007). Still today there is no official methodology accepted as to how landslide risk areas should be determined and defined in terms of mass movements (slides, slumps, rockfall, debris flows, etc.) (Mikoš et al., 2018).
- In September 2020, in order to finally execute the mitigation of large-scale landslides in Slovenia, such as the 2000 Stože Landslide, the Government of the Republic of Slovenia nominated a four-member Landslides Commission (Slov. Komisija za plazove), whose role is defined as follows (Vlada RS, 2020): "The Commission drafts proposals for remediation programs for the large-scale landslides triggered in 2000 and in 2001, proposals to the government for decisions on the allocation of funds for the implementation of measures on large-scale landslides, monitors the implementation of landslide remediation programs and the use of funds for measures, drafts proposals for government implementation of landslide remediation programs in each budget period, and for the entire duration of such programs, and drafts proposals for reports to the government on the use of funds for the implementation of measures in landslide-affected areas in each budget period and for the entire implementation period." The commission's composition covers relevant decision makers from four ministries of the Republic of Slovenia: Ministry of the Environment and Spatial Planning, of Infrastructure, of Defence, and of Finance, respectively. This new way will contribute to faster procedures and the final remediation of the 20-year old, large-scale landslides in Slovenia.

- Even 10 years after the disaster, general public perception speaks in favour of judgment-based risk management rather than quantitative risk assessment, a situation that can be explained by local inhabitants' poor understanding of the system, by low public involvement in the final remediation plan undertaken by the state agencies, and by the fact that the final remediation is still not finished (Mikoš, 2011a).

\subsection{Prevention against natural hazards and risks in Slovenia}

The Water Act (ZV-1, 2002), which was changed several times after its acceptance, the last version 
being accepted in 2020 (ZV-1-NPB8, 2020), includes the need to formally declare hazard and risk areas in Slovenia, including areas prone to landslides. The requisite formally accepted methodologies are still missing in 2021, preventing the production of landslide hazard and risk maps for all of Slovenia's territory. Though, preliminary methodology is used at the time being to prepare susceptibility maps in the selected Slovenian municipalities. Such landslide hazard and risk maps should be used in spatial planning procedures when coordinating land use in declared landslide hazard areas. The approach for landslide hazards should be the same as that for flood hazard and risk areas on the basis of the EU Floods Directive (2007), implemented in the Slovenian legislation as Rules on methodology to define flood risk areas and erosion areas connected to floods and classification of plots into risk classes (Pravilnik, 2007).

The development of the landslide risk reduction policy in Slovenia after the 2000 Stože Landslide started by analysing the phenomenology and dynamics of various types of mass movements, including debris flows (Ribičič, 2001; 2002). A strategy of modern protection against landslides was proposed by Ribičič and Mikoš (2002), firstly stressing the need for prevention, based on a national landslide database and hazard and risk maps with explanatory text. They proposed a structure for a digital landslide database that would cover all available data, from landslide triggering to remediation. Secondly, immediate remediation measures, and finally, measures for the long-lasting remediation of an active landslide were discussed. This paper was as a part of a modern monograph on natural disasters in Slovenia and protection against them (Ušeničnik, 2002). After two decades, a new edition on this topic is more than due.

The way forward started by developing methodologies within several targeted research projects (Slov. CRP - ciljni raziskovalni projekt) for recognising landslide hazards and risk areas - a distinction was made to develop one methodology for shallow landslides and the other one for debris flows (CRP 2004; 2008). The scales of hazards and risk maps were also proposed, namely 1:250,000 for overview maps and 1:25,000 for preliminary maps
(Đurović and Mikoš, 2004a). A special project was also dedicated to a mobile unit for immediate acquisition of spatial data in the event of landslides (CRP, 2007).

The methodology for susceptibility to shallow landsliding started at the Geological Survey of Slovenia (GeoZS) by applying a multivariate analysis of landslide causing factors in a GIS environment in the western part of Slovenia (Komac, 2004). Using factorial analysis, the most important spatial factors for landslide hazard were the underlying lithology and terrain slope (determined from Slovenian digital elevation model $25 \times 25 \mathrm{~m}$ ), followed by vegetation cover, terrain undulance: concavity \& convexity), and the proximity of watercourses and geological structural elements. Using multiple regression analysis, the most important spatial factors were characteristics of the surface types, such as maximal slope curvature, slope undulance, maximum slope inclination, and the prevailing lithological unit. The results of such a statistical analysis was the Landslide susceptibility map of Slovenia in the scale 1:250,000 (Komac \& Ribičič, 2006). Later on, a debris-flow susceptibility map in Slovenia was made at a scale of 1:250,000 (Komac et al., 2009; 2010), followed by a rockfall susceptibility map of Slovenia at a scale of 1:250,000 (Mikoš et al., 2013).

Zorn et al. (2012) conducted a review of mass movement susceptibility maps in Slovenia.

All such statistical models yielding the statistical probability of a landslide occurring at a given moment must be validated using a real landslide database (for a landslide database called GIS-UJME see CRP, 2005). At the end of the project to construct the Slovenian National Landslide Database, which ended in May 2005, there were more than 6600 registered landslides, of which almost half occurred at a known location and were accompanied with primary characteristic descriptions (Komac et al., 2007). Later, a web application was developed, called e-Plaz (Eng. eLandslide; https://www.e-plaz.si/), where anyone can report a landslide or erosion event. In the period 
Mikoš M.: After 2000 Stože Landslide: Part II - Development of landslide disaster risk reduction policy in Slovenia Po zemeljskem plazu Stože leta 2000: Del II - Razvoj politike zmanjševanja tveganja nesreč zaradi zemeljskih plazov v

Acta hydrotechnica 34/60 (2021), 39-59, Ljubljana

1996-April 2021, a total of 471 events were registered.

This achievement was further developed within the framework of a series of four national MASPREM projects (GeoZS 2013; 2016; 2018; 2019). These projects were dedicated to various sorts of mass movements (Slov. masni premiki) with the aim of developing a national rainfall-induced landslide early notifying and warning system called MASPREM.

Nowadays, the results of the susceptibility analysis of landsliding in Slovenia can be viewed for 34 out of 212 Slovenian municipalities as a web application called Geohazard in the form of a preliminary hazard map at a scale of $1: 25,000$ (https://geohazard.geo-zs.si/). There are 6 susceptibility classes defined: very high/high/medium/low/very low/negligible hazard. The processes covered in this preliminary methodology, which was updated in 2020 and must be formally adopted, are slope mass movements (rockfalls, slumps/slides), snow avalanches, and surface and linear soil erosion processes.

From a hydrological point of view, the development of a methodology for debris-flow hazard and risk assessment went a bit differently. The basis for the debris-flow hazard assessment was a combination of hydrological modelling of rainfall-runoff processes or empirical equations for design floods from ungauged torrential watersheds, with an estimation of sediment production in them (empirical equations for debris production in sediment sources) to assess debris-flow magnitudes (Sodnik and Mikoš, 2006). Further on, Sodnik (2009) investigated the mathematical modelling of debris flows and how debris-flow hazard maps can be prepared using mathematical tools - numerical models of debris flow dynamics (Sodnik and Mikoš, 2012). The use of mathematical modelling to assess debris-flow impacts on traffic lines was also studied, including impact of forest stands (Mikoš et al., 2012).

When Sodnik (2017) studied the formation of torrential fans and recognised landslides as debrisflow sources (Sodnik et al., 2017), a systematic methodology for debris-flow hazard assessment was proposed (Sodnik in Mikoš, 2018a; 2018b). They proposed a multiphase approach, incorporating the following phases:

- Preliminary classification of potentially hazardous areas

- Determination of labile (potentially unstable) areas in the selected torrential watershed

- Determination of the potential debris-flow magnitudes for each potentially unstable area

- Modelling of debris flow movement from their source areas to runout zones

- Production of debris-flow hazard maps

This proposed preliminary methodology is still not formally validated in a legislation act, but builds a good basis for such an act.

A recent study on design floods in ungauged small torrential watersheds in Slovenia showed that empirical equations used frequently to estimate extreme floods (e.g. $\mathrm{Q}_{500}$ ) in ungauged watersheds should be replaced by using hydrological-hydraulic modelling of rainfall-runoff process (Mikoš, 2020c). Therefore, a methodology for debris-flow hazard and risk assessment should incorporate such modelling as a constituent part of it.

\subsection{Natural disasters and insurance in Slovenia}

An underestimated factor is the position of the insurance sector in prevention against natural disasters.

Pavliha et al. (2002) studied risk insurance for natural disasters, and concluded that the implementation of optimal and integral insurance solutions against natural and other disasters in Slovenia would have several beneficial effects, including providing relief to the state budget, which remains the country's principal financer of rehabilitation following damage caused by natural and other disasters.

Ferlan and Mikoš (2004) analysed water-related disasters in Slovenia from 1990 to 1999, and based on data from Slovenia's largest insurance company found a growing share of non-life insurance in the reimbursement of damages caused by such 
disasters, as compared to state aid. They concluded that a discussion is needed on the possibility of introducing compulsory insurance against natural disasters for all property owners, comparable to compulsory car insurance.

Not much has changed since then in Slovenia regarding the distribution of costs to cover the costs of natural disasters between the state (public sector) and individual property owners (private sector). An OECD survey on disaster risk financing, its practices, and challenges is a good starting point (OECD, 2015).

The public sector still plays an important role in Slovenia in damage assessment and the collection of data on costs. Special damage assessment committees at local, regional, and national levels are in charge according to the Protection against Natural and Other Disasters Act (ZVNDN, 2010). Unfortunately, since 2007 the Statistical Office of the Republic of Slovenia has no longer collected estimated damages caused by natural disasters by type (for data until 2007 cf.: http://kazalci.arso.gov.si/en/content/estimateddamage-caused-natural-disasters). Slovenia must reestablish a national disaster loss database with detailed data on various types of disasters to comply with the Sustainable Development Goals 2030, as well as with selected targets of Sendai Framework for Disaster Risk Reduction.

\subsection{Landslide risk forecasting and early warning systems in Slovenia}

It is of paramount importance to monitor active landslides in order to assess their potential impacts and forecast their future advancement into the potential runout zone. According to Piciullo et al. (2020), landslide early warning systems can be categorized into two groups: territorial (dealing with several landslides at municipal/regional/national scale) and local (single landslide) systems.

For the 2000 Stože Landslide, a local alarm system was established for the event of another debris flow from the Stože source area. The system administrators asked for new electricity lines to power 4 alarm loops (wires across the valley at different heights) between the Stože Landslide source area and the national road Bovec-Predel. Any fast advancement of the landslide, especially a new debris flow, would have triggered an alarm using a public mobile alarm system and allowed for the fast evacuation of the villagers in Log pod Mangartom, as well as closed the road via a system of red traffic lights (Tavčar, 2001). After several years in operation, the system was dismantled, as other structural remediation measures were built in the area to protect Log pod Mangartom.

In the 2000s, new remote sensing techniques were developed that can be used for an early warning system (EWS) in the event of landslide risks. Among them, the PS-InSAR (Persistent Scatterer Interferometric Synthetic Aperture Radar) was a promising technique to detect field surface deformations in landslide-prone areas or on active landslides. This technique was introduced into geology and landslide research in Slovenia by Jemec Auflič (2012).

Planning and monitoring early warning systems for debris flows as fast flowing hazardous events is not an easy task. A review was prepared by Hübl and Mikoš (2014) and Mikoš and Hübl (2018).

The Slovenian national, real-time landslide prediction system, called MASPREM, was launched in September 2013. MASPREM forecasts landslide probability twice per day for 24 hours ahead based on landslide susceptibility maps, statistically defined landslide-triggering rainfall threshold values, and precipitation forecast models. The potential landslides areas are forecast at the national level (scale 1:250,000) and for selected municipalities at the local level (scale 1:25,000) (Jemec Auflič et al., 2018b).

The rainfall patterns for shallow landsliding in perialpine Slovenia were studied by Jemec Auflič and Komac (2013). Nevertheless, in the original MASPREM model, 24-h rainfall with the return period of 100 years has been used as a rainfall triggering parameter. Rainfall threshold values of various durations in Slovenia were reviewed in the companion paper by Mikoš (2020d). 
Mikoš M.: After 2000 Stože Landslide: Part II - Development of landslide disaster risk reduction policy in Slovenia Po zemeljskem plazu Stože leta 2000: Del II - Razvoj politike zmanjševanja tveganja nesreč zaradi zemeljskih plazov v

Acta hydrotechnica 34/60 (2021), 39-59, Ljubljana

Rainfall forecasts in Slovenia are issued by the Slovenian Environment Agency (Slov. ARSO Agencija Republike Slovenije za okolje) using the ALADIN-SI model. The development started in 1997 with a horizontal resolution of $12.5 \mathrm{~km}$ (Pristov et al., 2012), but was improved after that to a grid $4.5 \times 4.5 \mathrm{~km}$, yielding results every 6 hours for a period of 54 hours in advance.

The MASPREM system was tested for abundant precipitation between 9 and 14 September 2014, when around 800 slopes failed throughout Slovenia (Jemec Auflič et al., 2016). The study showed the need to account for antecedent rainfall in the MASPREM model.

The MASPREM system's first five years of operation were analysed by Jemec Auflič and Šinigoj (2019). The MASPREM system, based on the landslide susceptibility map of Slovenia, benefitted from a web application where users could report landslide events (e-Plaz: https://www.eplaz.si) (GeoZS, 2018), ensuring an additional dataset to validate the landslide forecast model. Also, a short-term, integrated nowcasting weather forecast (INCA) was incorporated into the MASPREM model to assess antecedent rainfall amounts in parallel to rainfall forecast by the ALADIN-SI model. In the future, new local rainfall thresholds as well as local hydrogeological and geological characteristics should be incorporated in the various forecast models in order to further improve the MASPREM model's reliability (Jemec Auflič and Šinigoj, 2019).

\subsection{Natural disasters in Slovenia}

According to the Slovenian Constitution (Constitution, 1991), in its Article No. 72 on a Healthy Living Environment, "everyone has the right in accordance with the law to a healthy living environment. The state shall promote a healthy living environment."

Zorn et al. (2009), when analysing natural disasters as a limiting development factor in Slovenia, focused on floods, concluding that we should rather adapt to natural processes such as floods, avalanches, or landslides, particularly through the available instruments of regional and spatial planning, rather than ignoring and underestimating them due to short-term economic, political, and other reasons.

For Slovenia, Zorn and Komac (2015) stated: "In the context of Slovenia, it can be legitimately asserted that responsibility for the effects of natural disasters should not only be ascribed to climate change or other environmental factors, because most often social reasons are more important." They presented four social reasons that reduce society's resilience to natural disasters: inadequate spatial planning, lack of supervision, insufficient insurance policies, and a mix of politics and capital influences.

The newest geographical overview on natural hazards in Slovenia was issued by Komac et al. (2019).

The Anton Melik Geographical Institute of the Research Centre of the Slovenian Academy of Sciences and Arts (ZRC SAZU; https://giam.zrcsazu.si/en/) (Slov. Geografski inštitut Antona Melika Znanstvenoraziskovalnega centra Slovenske akademije znanosti in umetnosti) is holding, together with the Administration of the Republic of Slovenia for Civil Protection and Disaster Relief (ACDPR; http://www.sos112.si/eng/) (Slov. Uprava Republike Slovenije za zaščito in reševanje), a triennial symposium on natural hazards in Slovenia: in 2008 (Zorn et al., 2010), 2011 (Zorn et al., 2011), 2014 (Zorn et al., 2014), 2017 (Zorn et al., 2017), 2020 (Zorn et al., 2020). Another important part of these symposia is also landslide research and landslide disaster risk reduction.

The newest Slovenian responses to global challenges related to natural disasters was designed by Komac (2020). He stresses the need for a dialogue between scientists and politicians in this regard. Furthermore, he recognises the importance of volunteering and public participation in risk management. Another important part of modern risk management is educating the general public and introducing natural hazards into curricula from primary schools to tertiary education and through the third Bologna cycle (doctoral studies). 
Mikoš M.: After 2000 Stože Landslide: Part II - Development of landslide disaster risk reduction policy in Slovenia Po zemeljskem plazu Stože leta 2000: Del II - Razvoj politike zmanjševanja tveganja nesreč zaradi zemeljskih plazov v

Acta hydrotechnica 34/60 (2021), 39-59, Ljubljana

How is spatial planning in Slovenia incorporated into prevention against natural disasters?

\section{Spatial development, regionalisation, and natural hazards in Slovenia}

Đurović and Mikoš (2004b) compared procedures for preventive risk management due to natural hazards in the Alpine countries and in Slovenia, and made an overview of legal bases for preventive risk management in Slovenia.

The design of the Spatial Development Plan for Slovenia (BF, 2002) proposed that it should follow the provisions from the new Water Act $(\mathrm{ZV}-1$, 2002) in order to respect recognised risk areas. The design proposed that risk areas should be accompanied by written definitions of measures that are needed to prevent damage through spatial policy procedures, i.e. restrictions on certain land uses, conditions for certain land uses, and declarations of no specific conditions or restrictions for other land uses. The Spatial Development Plan and the Spatial Development Strategy of the Republic of Slovenia (2004) also recognized that the increasing risk due to landslides as a type of natural hazard, together with floods, erosion, fires etc., is one of key problems due to human activity and inappropriate (reckless) use in water and riparian areas. In 2021, the new Spatial Development Strategy 2050 of the Republic of Slovenia should be finished. Protection against natural and other disasters is a part of the Strategy's draft version.

The integrated protection against natural hazards such as landslides was recognized as an important part of integrated water management (Mikoš, 2010a, 2011b). Alpine hazard and risk management in protected areas was discussed by Mikoš (2013) in the case of Slovenia's Triglav National Park. Prevention against landslides should also be seen as an important factor when planning the development of rural areas (Mikoš, 2010b). The step from passive and/or active protection against natural disasters to a culture of living with them was proposed in Slovenia by Mikoš (2015).

Prudent spatial development and regionalisation as an obligation and fulfilment for local self- government as defined in Article 143 of the Constitution of the Republic of Slovenia (Constitution, 1991) stating that: "a region is a selfgoverning local community that manages local affairs of wider importance, and certain affairs of regional importance provided by law" are, as such, also a key instrument to increase competitiveness of the Slovenian economy and a pillar for Slovenian sustainable development (Mikoš, 2020a; 2020b).

An important step was made in 2014, when the Slovenian National Platform for Disaster Risk Reduction (Slov. Svet Vlade Republike Slovenije za varstvo pred naravnimi in drugimi nesrečami; http://www.sos112.si/slo/page.php?src=sv10.htm) was established (Mikoš, 2018). After the first term, which ended in summer 2019, as of April 2021, the Platform still has not been renewed. This hinders the implementation of Slovenia's international obligations, as it has signed or ratified many international agreements or declarations, among others also the Sendai Framework for Disaster Risk Reduction 2015-2030. In April 2021, Slovenia is no longer on the list of 60 national platforms officially declared as national coordinating multi-sectoral and inter-disciplinary mechanisms for advocacy, coordination, analysis, and advice on disaster risk reduction.

\section{International cooperation of Slovenian landslide researchers}

The organised torrent control service in Slovenia, covering also protection against landslides, was organised during the Austro-Hungarian monarchy in 1884 (Jesenovec, 1995). For years on, the field of landslide disaster risk reduction in Slovenia was in the domain of torrent control under the auspices of forest management, and after 1966 it fell under water management (Mikoš, 2012). A short overview of Slovenia's international engagement in research on natural disasters was given more than a decade ago by Mikoš (2008).

\subsection{CIPRA and Alpine Convention}

In 1952, an autonomous non-governmental, nonprofit umbrella organisation called the International Commission for the Protection of the Alpine 
Regions (CIPRA; since 1990, the International Commission for the Protection of the Alps) was founded (Price, 2000).

The Convention on the Protection of the Alps (Alpine Convention, https://www.alpconv.org/) was initially signed in 1991; Slovenia signed it in 1993, and it came into effect in 1995.

An important contribution to CIPRA's activities was a methodologically innovative analysis of natural conditions in torrential watersheds (Pintar, 1977), shown in a case study from NW Slovenia for the assessment of a potential ski resort in a high Alpine environment. The study also included the methodological design of cartographic signs for natural conditions and natural processes that are jointly used to determine hazard areas endangered by (soil) erosion, avalanches, and landslides (mass movements), as well as for protection structures (torrential infrastructure).

This innovative management approach was further developed at the Water Management Institute in Ljubljana (Pintar and Mikoš, 1983), and subsequently applied for the water management plans of the Idrijca River (Zemljič et al., 1986), Pišenca Torrent (Pintar et al., 1987), the Sopota River (Pintar et al., 1989a), the Upper Soča River (Pintar et al., 1989b), and the Upper Sava River (Mikoš et al., 1996). With the new Slovenian Water Act (2002), based on the European Water Directive (EU, 2000), this development was stopped.

\subsection{The INTERPRAEVENT Research Society}

After severe floods in Europe in 1965 and 1966, the Research Association for Preventive Action against Flooding was established in Klagenfurt, Austria in 1968. In 1990, the association was renamed to the International Research Society INTERPRAEVENT (IP, www.interpraevent.at). This society's purpose is to establish preventive protection regimes against disasters, and to further interdisciplinary research in order to protect human living space against flooding, debris flow, landslides, avalanches, and rockfall, as well as anthropogenic (man-made) influences and destruction. The Society, among other activities, holds quadrennial international symposia.
A paper on land-use planning regarding natural conditions by Pintar (1980) may well be the first contribution from Slovenia to INTERPRAEVENT's 1980 regular symposium in Bad Ischl, followed by a contribution on the longterm management of torrential watersheds by Pintar and Mikoš (1984) to the INTERPRAEVENT Symposium in Villach.

The Republic of Slovenia (i.e. the Ministry of the Environment and Spatial Planning) joined as a regular member of the Society in 1997, but has never fully taken advantage of the existing knowledge network offered through this membership.

Nonetheless, Slovenia has since 1999 been a member of its Science \& Technology Advisory Board, which holds quadrennial Interpraevent congresses through Europe, also helping with congresses in the Pacific Rim area.

\subsection{International Consortium on Landslides}

The 2000 Stože Landslide sparked the beginning of a more interdisciplinary approach to landslide research in Slovenia, which led to the membership of several Slovenian academic institutions (e.g. the University of Ljubljana, Faculty of Civil and Geodetic Engineering \& Faculty of Natural Sciences and Engineering, Geological Survey of Slovenia) in the International Consortium on Landslides, Kyoto, Japan (https://icl.iplhq.org/). Risk dialogue in landslide disaster risk reduction found its way to more media exposure, culminating by hosting the 4th World Landslide Forum (WLF4) in 2017 in Ljubljana, Slovenia (https://wlf4.fgg.uni1j.si/; Mikoš et al., 2017; Alcántara-Ayala et al., 2017).

During the 4th World Landslide Forum the 2017 Ljubljana Declaration on Landslide Risk Reduction was adopted (Sassa, 2017). In this declaration, participants of WLF4 recognized the importance of the ISDR-ICL Sendai Partnerships 2015-2025 for the Global Promotion of Understanding and Reducing Landslide Disaster Risk (Sassa, 2015). These partnerships were proposed by ICL and signed by 22 global stakeholders to reduce landslide disaster risks - it is ICL's voluntary 
commitment to the United Nations World Conference on Disaster Risk Reduction, held in Sendai, Japan, 2015 (https://sendaicommitments.undrr.org/commitment s/20190110_001) (Mikoš, 2016). There are several types of partnerships and collaborative relationships (Stott and Murphy, 2020; Table 1, p. 7) for the Sustainable Development Goals and the United Nations Agenda 2030; the ISDR-ICL Sendai Partnerships 2015-2025 were recognized as those related to reducing disaster risk.

In 2019, ICL initiated a long-term global framework for promotion of understanding and reducing landslide disaster risk, called "The Kyoto 2020 Commitment for the Global Promotion of Understanding and Reducing Landslide Disaster Risk" (Kyoto Landslide Commitment 2020: KLC2020), with its first 57 signatories on November 2019 (Sassa, 2019). The Commitment was officially launched on November 2020 (Sassa, 2021). KLC2020 has 10 priority actions, e.g. priority action no. 1 aims at promoting "the development of people-centred early warning technology for landslides with increased precision and reliable prediction both in time and location, especially in a changing climate context" (Sassa, 2018). The planned contributions of the Faculty of Civil and Geodetic Engineering, an ICL member since 2008 and repeatedly proclaimed World Centre of Excellence in Landslide Risk Reduction (20082011, 2011-2014, 2014-2017, 2017-2020), to the KCL 2020 was summarised by Mikoš and Petkovšek (2019). The KLC2020 is directed to advocate for harmonic cohesiveness between the Sendai Landslide Partnerships 2015-2025, and the Sendai Framework for Disaster Risk Reduction (SF DRR), the 2030 Agenda Sustainable Development Goals, the New Urban Agenda and the Paris Climate Agreement (Alcántara-Ayala and Sassa (2020).

\section{Conclusions}

The effect of the 2000 Stože Landslide on landslide research in Slovenia is given in a companion paper (Mikoš, 2020d). Here we have summarised the development of landslide risk reduction policy in
Slovenia after this disaster. Combining the facts presented in the two papers, one can conclude that Slovenia is slowly placing more importance on the role of science and technology in reducing landslide disaster risks as part of more general disaster management.

More specifically, science and technology have an important value for the implementation of SF DRR, especially for its Priority Action 1 "Understanding disaster risk" (Satake et al., 2018). The role of science and technology should be bolstered in order to stress prevention and preparedness as parts of disaster risk management overreaction and response - as disaster risk should be considered a complex system of natural, societal, economic, and technological contexts. Furthermore, standardized scientific frameworks are required for monitoring, predicting, warning, evaluating, and mapping disaster risks for single or multiple hazardous events occurring simultaneously or successively.

Collaboration among and across scientists, policymakers, private sectors, and key stakeholder groups is critical for translating science-based knowledge into disaster risk reduction policies and practices through establishing and/or strengthening periodic and frequent communications (Satake et al., 2018).

Around the world, Landslide Early warning Systems (LEWS) are also becoming more popular, especially after being explicitly mentioned in the 4th priority for action of the Sendai Framework for Disaster Risk Reduction 2015-2030 (UNISDR, 2015 ; p. 21) at the national and local level: "To invest in, develop, maintain and strengthen peoplecentred multi-hazard, multisectoral forecasting and early warning systems, disaster risk and emergency communications mechanisms, social technologies and hazard-monitoring telecommunications systems; develop such systems through a participatory process; tailor them to the needs of users, including social and cultural requirements, in particular gender; promote the application of simple and low-cost early warning equipment and facilities; and broaden release channels for natural disaster early warning information." 
Recent developments in the field of LEWS have been intensive: Pecoraro et al. (2019) proposed monitoring strategies for local landslide early warning systems, Piciullo et al. (2018) described territorial early warning systems for rainfallinduced landslides, and later set standards for their performance assessment (Piciullo et al., 2020), and Calvello et al. (2020) proposed a new international network on landslide early warning systems called LandAware.

There is a clear call for Slovenian experts on landslide disaster risk reduction to join aforementioned activities. Especially the proposed LEWS for the Potoška Planina landslide above the Koroška Bela in NW Slovenia envisages such cooperation among experts. An international standard already exists for emergency management, offering guidelines for the implementation of a community-based LEWS (ISO, 2018b). According to the international standard on vocabulary in security and resilience (ISO, 2018a), a communitybased EWS is a method of communicating information to the public through established networks, and can consist of risk knowledge, monitoring, and warning services, dissemination and communication, and response capacities to avoid and reduce risks, and launch responses against disasters.

Jemec Auflič et al. (2019) investigated the understanding of landslide risk in the Koroška Bela community in NW Slovenia through learning by doing for case of the Potoška Planina landslide above the village of Koroška Bela.

Since the 2000 Stože Landslide, landslide disaster risk reduction in Slovenia has made important progress. Still, practical solutions and legislation lay beyond the level of science achieved by recent developments in landslide research, as presented in the companion paper (Mikoš, 2020d). In many ways the next steps await the state itself, which is primarily responsible for further development, especially in light of the numerous international obligations signed by the Republic of Slovenia.

There are some clear immediate tasks to be done, such as adopting all needed methodologies to produce hazard and risk maps, comparable to flood hazard and risk maps, in appropriate scales to be used as a prevention tool for multi-hazard assessment in spatial planning procedures as foreseen by the Water Act (2002). Also, the work of the Slovenian National Platform for Disaster Risk Reduction should be activated again so as to serve as a platform for the intersection of science and policy on natural hazard prevention and risk management.

\section{Acknowledgments}

The work on this manuscript was founded by the Slovenian Research Agency (ARRS) through research program P2-0180. The author would like to thank numerous colleagues for their enthusiastic cooperation and in-depth discussions in the field of landslide disaster risk reduction from many aspects and with different perspectives that we had in these two decades after the 2000 Stože Landslides.

\section{References}

Alcántara-Ayala, I., Sassa, K. (2020). Contribution of the International Consortium on Landslides to the implementation of the Sendai Framework for Disaster Risk Reduction: engraining to the Science and Technology Roadmap. Landslides https://doi.org/10.1007/s10346-020-01539-8.

Alcántara-Ayala, I., Sassa, K., Mikoš, M., Han, Q., Rhyner, J., Takara, K., Nishikawa, S., Rouhban, B., Briceño, S. (2017). The 4th World Landslide Forum: Landslide Research and Risk Reduction for Advancing the Culture of Living with Natural Hazards. International Journal of Disaster Risk Science 8(4), 498-502, https://doi.org/10.1007/s13753-017-0139-4.

Anonymous (1999). Tretje slovensko posvetovanje o zemeljskih plazovih, Rogla, 3. and 4.6.1999. (in Slovenian).

BF (2002). Krajina in prostorski razvoj Slovenije zasnova (Landscape and Spatial Development of Slovenia - design). University of Ljubljana, Biotechnical Faculty, Final report, 112 p., http://www.krajinskapolitika.si/wpcontent/uploads/2018/10/Krajina_in_prostorski_razvoj Slovenije.pdf.

Brilly, M., Mikoš, M., Šraj, M. (1999). Vodne ujme varstvo pred poplavami, erozijo in plazovi (Water-related 
Mikoš M.: After 2000 Stože Landslide: Part II - Development of landslide disaster risk reduction policy in Slovenia Po zemeljskem plazu Stože leta 2000: Del II - Razvoj politike zmanjševanja tveganja nesreč zaradi zemeljskih plazov v

Acta hydrotechnica 34/60 (2021), 39-59, Ljubljana

disasters - protection against, floods, erosion and landslides). Ljubljana, University of Ljubljana, Faculty of Civil and Geodetic Engineering, 186 p. (in Slovenian).

Calvello, M., Devoli, G., Freeborough, K., Gariano, S. L., Guzzetti, F., Kirschbaum, D., Nakaya, H., Robbins, J., Stähli, M. (2020). LandAware: a new international network on Landslide Early Warning Systems. Landslides 17, 2699-2702. https://doi.org/10.1007/s10346-020-01548-7.

Constitution (1991). Constitution of the Republic of Slovenia. Available at: https://www.us-rs.si/legalbasis/constitution/?lang=en (9 February 2021)

CRP (2004). Metodologija za določanje ogroženih območij in način razvrščanja zemljišč $\mathrm{V}$ razrede ogroženosti zaradi zemeljskih plazov (Methodology for determination of landslide risk areas and the classification in risk classes). Final report, 185 p. (in Slovenian).

http://www.sos112.si/slo/tdocs/met_zemeljski_1.pdf, http://www.sos112.si/slo/tdocs/met_zemeljski_2.pdf

CRP (2005). Novelacija in nadgradnja informacijskega sistema o zemeljskih plazovih in vključitev bazo GIS_UJME (Amendment and upgrade of the landslide information system and inclusion in the GIS_UJME database). Final Reports, 302 p. (in Slovenian) http://www.sos112.si/slo/tdocs/zem_plaz_gis_ujme.pdf, http://www.sos112.si/slo/tdocs/plazenja.pdf, http://www.sos112.si/slo/tdocs/nestabilnost_tal.pdf, http://www.sos112.si/slo/tdocs/merske_metode.pdf, http://www.sos112.si/slo/tdocs/metod_ukrep.pdf

CRP (2007). Mobilna enota za hitri zajem prostorskih podatkov v primeru zemeljskih plazov (Mobile unit for fast capture of spatial data in case of landslides). Final Report, $85 \quad$ p., $\quad$ (in Slovenian) http://www.sos112.si/slo/tdocs/naloga 73.pdf.

CRP (2008). Ocena ogroženosti zaradi delovanja drobirskih tokov (Debris-flow risk assessment). Final Report, 239 p. (in Slovenian) http://www.sos112.si/slo/tdocs/naloga 76.pdf.

Cvek, T. (Ed.) (1999). Zbornik predavanj: II. slovensko posvetovanje o zemeljskih plazovih, Šmarje pri Jelšah, 19. and 20.6.1997. Ljubljana. (in Slovenian)

Đurović, B., Mikoš, M. (2004a). Analiza tveganja zaradi nevarnosti masnega gibanja (Mass movements hazard analysis). 15. Mišičev vodarski dan 2004, Maribor, Zbornik del, $218-226$. http://www.mvd20.com/LETO2004/R29.pdf (in
Đurović, B., Mikoš, M. (2004b). Preventivno obvladovanje tveganj zaradi naravnih nevarnosti postopki $\mathrm{v}$ Alpskih državah in Sloveniji $=$ Preventive management of risks due to natural hazards - Procedures in the Alpine countries and in Slovenia. Acta hydrotechnica 22/36, 17-35, https://actahydrotechnica.fgg.uni-lj.si/paper/a36bd.pdf.

EU (2000). Directive 2000/60/EC of the European Parliament and of the Council of 23 October 2000 establishing a framework for Community action in the field of water policy. Official Journal of the European Union, L 327, 22.12.2000, 1-73.

Ferlan, M., Mikoš, M. (2002). Naravne nesreče in premoženjsko zavarovalništvo (Natural disasters and property insurance). In: Ušeničnik, B. (Ed.): Nesreče in varstvo pred njimi. Ljubljana: Uprava $\mathrm{RS}$ za zaščito in reševanje Ministrstva za obrambo, 545-552. http://www.sos112.si/slo/tdocs/varstvo.pdf (in Slovenian).

Froude, M.J., Petley, D.N. (2018). Global fatal landslide occurrence from 2004 to 2016. Natural Hazards and Earth System Sciences 18, 2161-2181. https://doi.org/10.5194/nhess-18-2161-2018.

Gariano, S. L., Guzzetti, F. (2016). Landslides in a changing climate. Earth-Science Reviews 162, 227-252. https://doi.org/10.1016/j.earscirev.2016.08.011.

GeoZS (2013). Sistem zgodnjega opozarjanja za primer nevarnosti proženja zemeljskih plazov - MASPREM (Landslide early warning system - MASPREM). Geološki zavod, Ljubljana, 461 p., http://www.sos112.si/slo/tdocs/naloga_100.pdf (in Slovenian).

GeoZS (2016). Nadgradnja sistema za obveščanje in opozarjanje $\mathrm{v}$ primeru proženja zemeljskih plazov MASPREM2 (Upgrade of the landslide early notifying and warning system - MASPREM2). Geološki zavod, Ljubljana, 113 p., http://www.sos112.si/slo/tdocs/naloga 103.pdf (in Slovenian).

GeoZS (2018). Nadgradnja sistema za obveščanje in opozarjanje v primeru proženja zemeljskih plazov v RS - MASPREM3 (Upgrade of the landslide early notifying and warning system - MASPREM3). Geološki zavod, Ljubljana, 175 p., http://www.sos112.si/slo/tdocs/naloga_105.pdf (in Slovenian).

GeoZS (2019). Nadgradnja sistema za obveščanje in opozarjanje v primeru proženja zemeljskih plazov v RS 
Mikoš M.: After 2000 Stože Landslide: Part II - Development of landslide disaster risk reduction policy in Slovenia Po zemeljskem plazu Stože leta 2000: Del II - Razvoj politike zmanjševanja tveganja nesreč zaradi zemeljskih plazov v

Acta hydrotechnica 34/60 (2021), 39-59, Ljubljana

- MASPREM4 (Upgrade of the landslide early notifying and warning system - MASPREM4). Geološki zavod, Ljubljana, 37 p. (in Slovenian).

Haque, U., Blum, P., da Silva, P.F., Andersen, P., Pilz, J., Chaloy, S.R., Malet, J.-P., Jemec Auflič, M., Andres, N., Poyiadji, E., Lamas, P.C., Zhang, W., Peshevski, I., Pétursson, H.G., Kurt, T., Dobrev, N., García-Davalillo, J.C., Halkia, M., Ferri, S., Gaprindashivili, G., Engström, J., Keellings, D. (2016). Fatal landslides in Europe. Landslides 13, 1545-1554. https://doi.org/10.1007/s10346-016-0689-3.

Herrera, G. et al. (2018). Landslide databases in the Geological Surveys of Europe. Landslides 15(2), 359379, https://doi.org/10.1007/s10346-017-0902-z.

Hübl, J., Mikoš, M. (2014). Debris flow monitoring. Wildbach- und Lawinenverbau 78/173, 50-66.

Hungr, O., Leroueil, S., Picarelli, L. (2014). The Varnes classification of landslide types, an update. Landslides 11, 167-194. https://doi.org/10.1007/s10346-013-0436$\mathrm{y}$

ISO (2018a). ISO 22300:2018(en) Security and resilience - Vocabulary. Geneva: International Organization for Standardization.

ISO (2018b). ISO 22327:2018(en) Security and resilience - Emergency management — Guidelines for implementation of a community-based landslide early warning system. Geneva: International Organization for Standardization.

Jemec Auflič, M. (2012). Uporaba metode permanentnih sipalcev $\mathrm{v}$ geologiji kot podpora pri proučevanju plazljivih območij (Application of the permanent scatterers technique in geology as a support for the landslide prone areas investigation). $\mathrm{PhD}$ Thesis, Faculty of Natural Sciences and Engineering, University of Ljubljana, 197 p.

Jemec Auflič, M., Komac, M. (2013). Rainfall patterns for shallow landsliding in perialpine Slovenia. Natural hazards 67/3, 1011-1023, https://doi.org/10.1007/s11069-011-9882-9.

Jemec Auflič, M., Šinigoj, J. (2019). Vrednotenje sistema MASPREM po petih letih testnega delovanja: izboljšave in prihodnje naloge (Evaluation of MASPREM system after five years of testing operations: improvements and future tasks). Ujma 33, 204-210, http://www.sos112.si/slo/tdocs/ujma/2019/204-210.pdf (in Slovenian).

Jemec Auflič, M., Šinigoj, J., Krivic, M., Podboj, M., Peternel, T., Komac, M. (2016). Landslide prediction system for rainfall induced landslides in Slovenia (Masprem). Geologija 59/2, 259-271, http://dx.doi.org/10.5474/geologija.2016.016.

Jemec Auflič, M., Mikoš, M., Verbovšek, T., Bavec, M. (2018a). Recent developments in landslide research in Slovenia. In: Jemec Auflič, M., Mikoš, M., Verbovšek, T. (Eds.): Advances in Landslide Research. Proceedings of the 3rd Regional Symposium on Landslides in the Adriatic-Balkan Region, 11-13 October 2017, Ljubljana. Geological Survey of Slovenia. 119-124. https://www.geo-

zs.si/PDF/Monografije/Advances_landslide_research.pd $\underline{\mathrm{f}}$

Jemec Auflič, M., Šinigoj, J., Peternel, T., Podboj, M., Krivic, M., Komac, M. (2018b). TXT-tool 2.386-2.1 A System to Forecast Rainfall-Induced Landslides in Slovenia. In: Sassa, K. et al. (Eds): Landslide Dynamics: ISDR-ICL Landslide Interactive Teaching Tools. Springer, Cham. https://doi.org/10.1007/978-3-31957774-6_29.

Jemec Auflič, M., Kumelj, Š., Peternel, T., Jež, J. (2019). Understanding of landslide risk through learning by doing: case study of Koroška Bela community, Slovenia. Landslides 16(9), 1681-1690, https://doi.org/10.1007/s10346-018-1110-1.

Jesenovec, S. (Ed.) (1995). Pogubna razigranost - 110 let organiziranega hudourničarstva na Slovenskem 1884-1994 (Disastrous playfulness - 110 years of organised Torrent Control Service in Slovenia 18841994). Ljubljana: Podjetje za urejanje hudournikov, 276 p. (in Slovenian)

Komac, M. (2004). Model stopnje ogroženosti plazov na osnovi multivariatne analize (Landslide-exposed areas modeling using the multivariate analysis). Geologija 47/2,

237-247, https://doi.org/10.5474/geologija.2004.019 (in Slovenian with English abstract)

Komac, M. (2017). Preučevanje zemeljskih plazov v Sloveniji v preteklih dveh desetletjih $\mathrm{z}$ vidika geologije in sorodnih ved ter predstavitev primera metodologije prostorske analize pojavljanja zemeljskih plazov (The geological and geology-related study of landslides in Slovenia in the past two decades and the presentation of methodology of spatial analysis of the landslides occurrence). Ujma 31, 161-170, Available at: http://www.sos112.si/slo/tdocs/ujma/2017/161-170.pdf (in Slovenian)

Komac, B. (2020). Domači odzivi na globalne izzive v Sloveniji in Evropi (Local responses to global challenges 
Mikoš M.: After 2000 Stože Landslide: Part II - Development of landslide disaster risk reduction policy in Slovenia -

Po zemeljskem plazu Stože leta 2000: Del II - Razvoj politike zmanjševanja tveganja nesreč zaradi zemeljskih plazov v

Acta hydrotechnica 34/60 (2021), 39-59, Ljubljana

in Slovenia and Europe). In: Zorn, M., Komac, B., Ciglič, R., Logar, E. (Eds.): Domači odzivi na globalne izzive, Naravne nesreče $\quad \mathbf{5}$ 11-25, https://doi.org/10.3986/NN0501.

Komac, M., Ribičič, M. (2006). Landslide susceptibility map of Slovenia at scale 1:250,000. Geologija 49(2), 295-309, https://doi.org/10.5474/geologija.2006.022.

Komac, M., Hribernik, K. (2015). Slovenian national landslide database as a basis for statistical assessment of landslide phenomena in Slovenia. Geomorphology 249 , 94-102,

https://doi.org/10.1016/j.geomorph.2015.02.005.

Komac, M., Fajfar, D., Ravnik, D., Ribičič, M. (2007). Slovenian National Landslide DataBase - A promising approach to slope mass movement prevention plan. Geologija $\quad \mathbf{5 0 / 2}, \quad 393-402$, https://doi.org/10.5474/geologija.2007.027.

Komac, B., Ferk, M., Pipan, P., Tičar, J., Zorn, M. (2019). Natural Hazards in Slovenia. In: Preko, D., Ciglič, R., Zorn, M. (Eds.): The Geography of Slovenia, World Regional Geography Book Series, Springer Nature, Chapter 17, 259-277. https://link.springer.com/chapter/10.1007/978-3-03014066-3 17.

Komac, M., Kumelj, Š., Ribičič, M. (2009). Model dovzetnosti za pojavljanje drobirskih tokov v Sloveniji v merilu 1:250.000 (Debris-flow susceptibility model of Slovenia at scale 1:250,000). Geologija 52(1), 87-104, https://doi.org/10.5474/geologija.2009.010

(in

Slovenian).

Komac, M., Kumelj, Š., Ribičič, M., Mikoš, M. (2010). Debris-flow susceptibility model of Slovenia at scale 1:250,000. In: Chen, S.-C. (Ed.). INTERPRAEVENT 2010, Taipei, Taiwan, 786-796. http://www.interpraevent.at/palm-

cms/upload_files/Publikationen/Tagungsbeitraege/2010 786.pdf

Krajnc, M. (2004). Krizno upravljanje in vodenje Primer: Log pod Mangartom) (Crisis Management and Leadership). Diploma Thesis, University of Ljubljana, Faculty of Social Sciences, 63 p., https://repozitorij.unilj.si/Dokument.php?id=6697 (in Slovenian).

Malešič, M. (2020). Disaster response from a comparative perspective. International Journal of Disaster Risk Reduction 48, 101621, https://doi.org/10.1016/j.ijdrr.2020.101621.

Mikoš, M. (2008). Mednarodna vpetost Slovenije v raziskovanje naravnih nesreč (International engagement of Slovenia into research on natural disasters), Geografski obzornik 55(3), 4-9, $\underline{\text { http://zgs.zrc- }}$ sazu.si/Portals/8/Geografski_obzornik/go_2008_3.pdf (in Slovenian).

Mikoš, M. (2010a). Regionalizacija Slovenije in integralno upravljanje $\mathrm{z}$ vodami (Regionalisation of Slovenia and Integrated Water Management). In: Hvala, I. (Ed.): Demokratične vrednote in aktivno državljanstvo: pokrajine, participacija, meje in odnosi s sosedi: trije posveti (Ljubljana: Društvo Občanski forum), 111-116 (in Slovenian).

Mikoš, M. (2010b). Razvoj slovenskega podeželja z vidika integriranega varstva pred naravnimi nevarnostmi (Development of Slovenian rural areas from integrated natural hazard protection point of view). In: Zavodnik Lamovšek, A., Fikfak, A., Barbič, A. (Eds): Podeželje na preizkušnji: jubilejna monografija ob upokojitvi izrednega profesorja dr. Antona Prosena. Fakulteta za gradbeništvo in geodezijo Univerze $\mathrm{v}$ Ljubljani \& Geodetski inštitut Slovenije, 177-185 (in Slovenian).

Mikoš, M. (2011a). Public Perception and Stakeholder Involvement in the Crisis Management of SedimentRelated Disasters and their Mitigation: The Case of the Stože Debris Flow in NW Slovenia. Integrated Environmental Assessment and Management 7(2), 216227, https://doi.org/10.1002/ieam.140.

Mikoš, M. (2011b). Integralno upravljanje voda in regionalizacija Republike Slovenije (Integrated water management and regionalization of the Republic of Slovenia). Geodetski vestnik 55/3, 518-529, http://www.geodetski-vestnik.com/55/3/gv55-3 518529.pdf.

Mikoš, M. (2012). Prispevek k zgodovinskemu pregledu razvoja hudourništva in hudourničarstva v Sloveniji (A Contribution to History of Torrent Control Theory and Practice in Slovenia). Gozdarski vestnik 70(10), 429-439 (in Slovenian with English abstract).

Mikoš, M. (2013). Upravljanje gorskih nevarnosti in tveganj $\mathrm{v}$ zavarovanih območjih: primer Triglavskega narodnega parka, Slovenija (Alpine hazard and risk management in protected areas: The case of the Triglav National Park, Slovenia). Geodetski vestnik 57/1, 112124, (in Slovenian) http://www.geodetskivestnik.com/images/57/1/gv57-1_mikos.pdf

Mikoš, M. (2015). Od varstva pred naravnimi tveganji do kulture sobivanja $\mathrm{z}$ njimi (From protection against natural disasters to culture of living with them). 26. Mišičev vodarski dan 2015, Maribor, Zbornik del, 7-13. 
Mikoš M.: After 2000 Stože Landslide: Part II - Development of landslide disaster risk reduction policy in Slovenia Po zemeljskem plazu Stože leta 2000: Del II - Razvoj politike zmanjševanja tveganja nesreč zaradi zemeljskih plazov v

Acta hydrotechnica 34/60 (2021), 39-59, Ljubljana

http://www.mvd20.com/LETO2015/R5.pdf

(in Slovenian).

Mikoš, M. (2016). Slovenija in 3. Svetovna konferenca Združenih narodov o zmanjšanju tveganja nesreč, Sendai, Japonska, 2015 (Slovenia and the 3rd United Nations World Conference on Disaster Risk Reduction, Sendai, Japan, 2015). Ujma 30, 309-316, http://www.sos112.si/slo/tdocs/ujma/2016/309-316.pdf

Mikoš, M. (2018). Landslide Risk Reduction and the Slovenian National Platform on Disaster Risk Reduction. In: Jemec Auflič, M., Mikoš, M., Verbovšek, T. (Eds.): Advances in Landslide Research. Proceedings of the 3rd Regional Symposium on Landslides in the AdriaticBalkan Region, 11-13 October 2017, Ljubljana. Geological Survey of Slovenia. 149-154, https://www.geo-

zs.si/PDF/Monografije/Advances_landslide_research.pd $\underline{\mathrm{f}}$

Mikoš, M. (2020a). Regionalizacija Slovenije kot instrument za dvig konkurenčnosti gospodarstva in dolgoročni vzdržni razvoj (Regionalization of Slovenia as an instrument for raising competitiveness of the economy and long-term sustainable development of Slovenia). Gradbeni vestnik 69(5), 118-130, http://www.zveza-dgits.si/13111/pdf:1 (in Slovenian)

Mikoš, M. (2020b). Regionalizacija Slovenije kot instrument za dvig konkurenčnosti gospodarstva in dolgoročni vzdržni razvoj (Regionalisation of Slovenia as an Instrument to Boost Competitiveness of Economy and Long-term Sustainable Development). In: Brezovnik, B., Holcman, B., Trpin, G. (Eds.): Pokrajine v Sloveniji $=$ Regions in Slovenia, Inštitut za lokalno samoupravo Maribor, Lex Localis, 87-110, https://doi.org/10.4335/978-961-6842-97-6.6 (in Slovenian).

Mikoš, M. (2020c). Poplavna nevarnost v Sloveniji in ocena ekstremnih projektnih poplavnih pretokov (Flood hazard in Slovenia and assessment of extreme design floods). Acta hydrotechnica 33(58), 43-59, https://doi.org/10.15292/acta.hydro.2020.04.

Mikoš, M. (2020d). After 2000 Stože Landslide: Part I Development of landslide research in Slovenia. Acta hydrotechnica $\quad 33(\mathbf{5 9}), \quad 129-153$, https://doi.org/10.15292/acta.hydro.2020.09.

Mikoš, M., Hübl. J. (2018). Practice guidelines on monitoring and warning technology for debris flows: TXT-tool 2.386-1.2. Sassa, K., Guzzetti, F., Yamagishi, H., Arbanas, Ž., Casagli, N., McSaveney, M., Dang, K. (Eds.): Landslide Dynamics: ISDR-ICL landslide interactive teaching tools. Vol. 1, Fundamentals, mapping and monitoring. Berlin: Springer, 567-585, https://doi.org/10.1007/978-3-319-57774-6_41.

Mikoš, M., Petkovšek, A. (2019). Faculty of Civil and Geodetic Engineering, University of Ljubljana. Landslides $\quad \mathbf{1 6}(9), \quad 1815-1819$, https://doi.org/10.1007/s10346-019-01231-6

Mikoš, M., Pintar, J., Rojnik, F., Smiljić, L., Škrlj, J. (1996). Vodnogospodarski načrt povodja Save Dolinke (Water Management Plan for the Sava Dolinka River). Ljubljana: Vodnogospodarski inštitut, 91 p. (in Slovenian).

Mikoš, M., Fazarinc, R., Majes, B. (2007). Delineation of risk area in Log pod Mangartom due to debris flows from the Stože landslide. Acta geographica Slovenica 47(2), 171-198, https://doi.org/10.3986/AGS47202.

Mikoš, M., Bavec, M., Celarc, B., Fidej, G., Jež, J., Podobnikar, T., Sodnik, J. (2012). Vpliv drobirskih tokov na prometnice - rezultati evropskega raziskovalnega projekta PARAmount (Impact of debris flows on traffic lines - results of European). In: Referati = Proceedings . 11. slovenski kongres o cestah in prometu $=11$ th Slovenian Road and Transport Congress, Portorož, 24.25. oktobra 2012. Ljubljana: DRC, Družba za raziskave $\mathrm{v}$ cestni in prometni stroki Slovenije, 1-8.

Mikoš, M., Jemec, M., Ribičič, M., Čarman, M., Komac, M. (2013). Earthquake-Induced Landslides in Slovenia: Historical Evidence and Present Analyses. In: Ugai, K., Yagi, H., Wakai, A. (Eds.): Earthquake-Induced Landslides. Springer Verlag, 223-231.

https://doi.org/10.1007/978-3-642-32238-9_23.

Mikoš, M., Čarman, M., Papež, J., Janža, M. (2014). Legislation and procedures for the assessment of landslide, rockfall and debris flow hazards and risks in Slovenia. Wildbach- und Lawinenverbau 78/174, 212221.

Mikoš, M., Čarman, M., Papež, J., Jež, J. (2018). TXTtool 4.386-1.1: State-of-the-Art Overview on Landslide Disaster Risk Reduction in Slovenia. In: Sassa, K., Tiwari, B., Liu, KF., McSaveney, M., Strom, A., Setiawan, H. (Eds.): Landslide Dynamics: ISDR-ICL Landslide Interactive Teaching Tools. Springer, Cham, 683-691, https://doi.org/10.1007/978-3-319-577777_43.

Mikoš, M. Yin, Y., Sassa, K. (2017). The Fourth World Landslide Forum, Ljubljana, 2017. Landslides 14, 18431854. https://doi.org/10.1007/s10346-017-0889-5. 
Mikoš M.: After 2000 Stože Landslide: Part II - Development of landslide disaster risk reduction policy in Slovenia Po zemeljskem plazu Stože leta 2000: Del II - Razvoj politike zmanjševanja tveganja nesreč zaradi zemeljskih plazov v

Acta hydrotechnica 34/60 (2021), 39-59, Ljubljana

OECD (2015). Disaster Risk Financing - A global survey of practices and challenges. Paris: OECD Publishing, 135 p., Available at: http://dx.doi.org/10.1787/9789264234246-en (9.2.2021)

Ozturk, U., Pittore, M., Behling, R., Roessner, S., Andreani, L., Korup, O. (2020). How robust are landslide susceptibility estimates? Landslides (in print). https://doi.org/10.1007/s10346-020-01485-5.

Pavliha, M., Oblak, S., Moljk, R., Vlačič, P. (2002). Zavarovanje tveganj pred naravnimi nesrečami (Risk Insurance against Natural Disasters). Ujma 16, 250-255. http://www.sos112.si/slo/tdocs/ujma/2002/u06.pdf (in Slovenian).

Pecoraro, G., Calvello, M., Piciullo. L. (2019) Monitoring strategies for local landslide early warning systems. Landslides 16, 213-231. https://doi.org/10.1007/s10346-018-1068-z.

Piciullo, L., Calvello, M., Cepeda, J. M. (2018) Territorial early warning systems for rainfall-induced landslides. Earth-Science Reviews 179, 228-247. https://doi.org/10.1016/j.earscirev.2018.02.013.

Piciullo, L., Tiranti, D., Pecoraro, G., Cepeda, J. M., Calvello, M. (2020). Standards for the performance assessment of territorial landslide early warning systems. Landslides $\quad \mathbf{1 7 ( 1 1 ) ,}$ 2533-2546, https://doi.org/10.1007/s10346-020-01486-4.

Pintar, J. (1977). Metodološka zasnova analize povirij voda s primerjalno presojo primernosti površin za smučišča $v$ povirju Pišence (Methodological design of analysis of torrential watersheds with comparative assessment of the suitability of areas for ski resorts in the Pišence Torrent watershed). Ljubljana: Podjetje za urejanje hudournikov \& LIZ Inženiring, 65 p. (in Slovenian)

Pintar, J. (1980). Lenkung der Raumnutzung durch stufenweises Ausscheiden der Nutzungsfläche auf Grund ihrer maßgeblichen, naturräumlichen Parameter (Orientation of Land Programming and Land Use Based by Gradual Eliminations of Suitable Areas by Determination of Natural-Conditioned Parameters). In: Internationales Symposion INTERPRAEVENT 1980, Bad Ischl, Austria, Vol. 3, 195-203, Available at: http://www.interpraevent.at/palm-

cms/upload_files/Publikationen/Tagungsbeitraege/1980

3_195.pdf (in German with English abstract)

Pintar, J., Mikoš, M. (1983). Izdelava smernic in normativov $\mathrm{z}$ globalno usmeritvijo urejanja po ekosistemih, pojavnosti in ekološki primernosti ter načinov gospodarjenja s povirji voda (Development of guidelines and norms with a global orientation of regulation by ecosystems, occurrences and ecological suitability, as well as management methods of torrential watersheds). Ljubljana: Vodnogospodarski inštitut, Research Report C-432, 106 p. (in Slovenian).

Pintar, J., Mikoš, M. (1984). Zugang zu der langfristigen Planung der Bewirtschaftung von Wassereinzugsgebieten (The approach to the long-term planning of watersheds management). In: Internationales Symposion INTERPRAEVENT 1984, Villach, Austria, Band 3, 205-220 (in German).

Pintar, J., Batistič, M., Mikoš, M., Šolar, M., Zemljič, M. (1987). Vodnogospodarska ureditev povirja Pišnice (Water Management Plan for the Pišenca Torrent). Ljubljana: Vodnogospodarski inštitut (in Slovenian).

Pintar, J., Mikoš, M., Šolar, M. (1989a). Ureditvene zasnove območja Sopote (Design Concept of the Sopota River Management Plan). Ljubljana: Vodnogospodarski inštitut, Report C-539, 100 p. (in Slovenian).

Pintar, J., Mikoš, M., Šolar, M., Fazarinc, R., Kovačič, I., Colarič, O. (1989b). Vodnogospodarska ureditev povodja zgornje Soče (Water Management Plan for the Upper Soča River basin). Ljubljana: Vodnogospodarski inštitut, 92 p. (in Slovenian).

Pravilnik (2007). Pravilnik o metodologiji za določanje območij, ogroženih zaradi poplav in z njimi povezane erozije celinskih voda in morja, ter o načinu razvrščanja zemljišč v razrede ogroženosti (Rules on methodology to define flood risk areas and erosion areas connected to floods and classification of plots into risk classes). Official Gazette of the Republic of Slovenia 60, 83758386. https://www.uradni-list.si/glasilo-uradni-list-

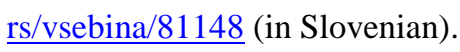

Price, M. F. (2000). The Alpine Convention: A Model for Other Mountain Regions? Mountain Research and Development 20(2), 192-194.

Pristov, N., Cedilnik, J., Jerman, J., Strajnar, B. (2012). Priprava numerične meteorološke napovedi ALADIN-SI Preparation of numerical meteorological forecast ALADIN-SI). Vetrnica 4, 17-23, http://www.meteodrustvo.si/data/upload/Vetrnica_0412.pdf (in Slovenian).

Režun, B., Janež, J., Trauner, L., Špacapan, I. (Eds.) (1994). Prvo slovensko posvetovanje o zemeljskih plazovih, Idrija, 17. in 18. november, 1994. Idrija: Rudnik živega srebra (in Slovenian). 
Mikoš M.: After 2000 Stože Landslide: Part II - Development of landslide disaster risk reduction policy in Slovenia Po zemeljskem plazu Stože leta 2000: Del II - Razvoj politike zmanjševanja tveganja nesreč zaradi zemeljskih plazov v

Acta hydrotechnica 34/60 (2021), 39-59, Ljubljana

Ribičič, M. (2001). Značilnosti drobirskega toka Stože pod Mangartom (Debris Flow at Log pod Mangartom). Ujma 14-15, 102-108. http://www.sos112.si/slo/tdocs/ujma/2001/p3 6.pdf (in Slovenian).

Ribičič, M. (2002). Zemeljski plazovi, usadi in podori (Landslides, slumps, and rockfalls). In: Ušeničnik, B. (Ed.): Nesreče in varstvo pred njimi. Ljubljana: Uprava RS za zaščito in reševanje Ministrstva za obrambo, 260 266.

http://www.sos112.si/slo/tdocs/naravne nesrece.pdf (in Slovenian).

Ribičič, M., Mikoš, M. (2002). Varstvo pred zemeljskimi plazovi (Protection against landslides). In: Ušeničnik, B. (Ed.): Nesreče in varstvo pred njimi. Ljubljana: Uprava RS za zaščito in reševanje Ministrstva za obrambo, 523 532. http://www.sos112.si/slo/tdocs/varstvo.pdf (in Slovenian).

Ribičič, M., Buser, I., Hoblaj, R. (1994). Digital attribute/table landslide database in Slovenia as a basis for field data gathering. In: Režun, B., Janež, J., Trauner, L., Špacapan, I. (Eds.): First Slovenian Landslide Conference. Idrija: Rudnik živega srebra, 139-153. (in Slovenian)

Sassa, K. (2015). ISDR-ICL Sendai Partnerships 20152025 for global promotion of understanding and reducing landslide disaster risk. Landslides 12(4), 631-640. https://doi.org/10.1007/s10346-015-0586-1.

Sassa, K. (2017). The 2017 Ljubljana Declaration on landslide risk reduction and the Kyoto 2020 Commitment for global promotion of understanding and reducing landslide disaster risk. Landslides 14, 1289-1296, https://doi.org/10.1007/s10346-017-0857-0.

Sassa, K. (2018). Zero Draft of the Kyoto 2020 Commitment for Global Promotion of Understanding and Reducing Landslide Disaster Risk. Landslides 15, 389-392, https://doi.org/10.1007/s10346-017-0937-1.

Sassa, K. (2019). The Kyoto Landslide Commitment 2020: First Signatories. Landslides 16(11), 2053-2057. https://doi.org/10.1007/s10346-019-01295-4.

Sassa, K. (2021). The Kyoto Landslide Commitment 2020: launched. Landslides 18, 5-20,

Satake, K., McLean, C., Alcántara-Ayala, I. (2018). Understanding disaster risk: the role of science and technology. J Dis Res 13(7), 1168-1176. https://doi.org/10.20965/jdr.2018.p1168.

Sodnik, J. (2009). Matematično modeliranje drobirskih tokov in priprava podrobnih kart nevarnosti
(Mathematical modeling of debris flows and preparing of hazard maps). MSc Thesis Nr. 215, University of Ljubljana, Faculty of Civil and Geodetic Engineering, 214 p., http://drugg.fgg.uni-lj.si/761/ (in Slovenian).

Sodnik, J. (2017). Ocenjevanje nevarnosti zaradi delovanja drobirskih tokov na hudourniških vršajih (Debris flow hazard assessment on torrential fans). $\mathrm{PhD}$ Thesis, University of Ljubljana, Faculty of Civil and Geodetic Engineering, 200 p., https://repozitorij.unilj.si/Dokument.php?id=108683 (in Slovenian).

Sodnik, J., Mikoš, M. (2006). Estimation of magnitudes of debris flows in selected torrential watersheds in Slovenia = Ocena magnitud drobirskih tokov v izbranih hudourniških območjih v Sloveniji. Acta geographica Slovenica $\quad \mathbf{4 6 ( 1 ) ,}$ 93-123. https://doi.org/10.3986/AGS46104.

Sodnik, J., Mikoš, M. (2012). Recent developments in assessing debris-flow hazard in Slovenia. In: Ožanić, N. et al. (Eds.): Monitoring and analyses for disaster mitigation of landslides, debris flow and floods: book of proceedings. 2nd Project Workshop of the Croatia Japan Project on Risk Identification and Land-use Planning for Disaster Mitigation of Landslides and Floods in Croatia, 15-17 December 2011, Rijeka. Rijeka: University of Rijeka, 159-162, https://rektor.uniri.hr/files/staticki_dio/zbornik\%20rado va\%20-\%202\%20radionica-1.pdf

Sodnik, J., Mikoš, M. (2018a). Zemeljski plazovi pri ocenjevanju nevarnosti zaradi delovanja drobirskih tokov (Landslides at debris flow hazard assessment). Gradbeni vestnik 67(6), 120-131, http://www.zvezadgits.si/12708/pdf:1 (in Slovenian).

Sodnik, J., Mikoš, M. (2018b). Predlog metodologije za ocenjevanje nevarnosti zaradi delovanja drobirskih tokov (Methodology proposal for debris-flow hazard assessment). 29. Mišičev vodarski dan, Maribor, Zbornik del, 57-65, http://www.mvd20.com/LETO2018/R7.pdf (in Slovenian).

Sodnik, J., Kumelj, Š., Peternel, T., Jež, J., Maček, M. (2017). Identification of landslides as debris flow sources using a multi-model approach based on a field survey Koroška Bela, Slovenia. In: Tiwari, B., Yin, Y., Sassa, K. (Eds.): Advancing Culture of Living with Landslides. Vol. 2, 1121-1128, https://doi.org/10.1007/978-3-31953498-5 127.

Stott, L., Murphy, D.F. (2020). An Inclusive Approach to Partnerships for the SDG's: Using a Relationship Lens to Explore the Potential for Transformational 
Mikoš M.: After 2000 Stože Landslide: Part II - Development of landslide disaster risk reduction policy in Slovenia Po zemeljskem plazu Stože leta 2000: Del II - Razvoj politike zmanjševanja tveganja nesreč zaradi zemeljskih plazov v Sloveniji

Acta hydrotechnica 34/60 (2021), 39-59, Ljubljana

Collaboration. Sustainability 12, 7905. http://dx.doi.org/10.3390/su12197905.

Tavčar, B. (2001). Mobilni sistem javnega alarmiranja v Logu pod Mangartom (Mobile Public Alerting System in Log pod Mangartom). Ujma 14-15, 118-121. http://www.sos112.si/slo/tdocs/ujma/2001/p3_8.pdf (in Slovenian).

UNISDR (2015). Sendai Framework for Disaster Risk Reduction 2015-2030. Geneva: United Nations. 36 p. https://www.preventionweb.net/files/43291_sendaifram eworkfordrren.pdf (9 February 2021)

Uredba (2004). Uredba o pogojih in omejitvah gradnje na območju Loga pod Mangartom, ogroženem zaradi pojava drobirskih tokov (Decree on the conditions and limitations of construction in the area of Log pod Mangartom under threat debris flows). Official Gazette of the Republic of Slovenia 87, 10622-10638. https://www.uradni-list.si/_pdf/2004/Ur/u2004087.pdf (2 February 2021)

Ušeničnik, B. (2001). Posledice in ukrepanje ob nesreči (Consequences of and Response to the Disaster). Ujma 14-15, 67-79. http://www.sos112.si/slo/tdocs/ujma/2001/p3_2.pdf (in Slovenian).

Ušeničnik, B. (Ed.) (2002). Nesreče in varstvo pred njimi (Natural disasters and protection). Ljubljana: Uprava RS za zaščito in reševanje Ministrstva za obrambo, 569 p., http://www.sos112.si/slo/tdocs/nesrece_varstvo1.pdf (in Slovenian).

Vlada RS (2020). Sporočilo za javnost - 33. redna seja Vlade Republike Slovenije (Press release - 33. Regular Meeting of the Government of the Republic of Slovenia). 23.9.2020, 37 p., https://www.gov.si/assets/vlada/Sejavlade-SZJ/2020/09-2020/SPsevl33a.doc (in Slovenian).

WWDR (2020). The United Nations World Water Development Report 2020: Water and Climate Change. United Nations Educational, Scientific and Cultural Organization, Paris. 219 p., https://unesdoc.unesco.org/ark:/48223/pf0000372985.lo cale=en.

Zemljič, M., Pintar, J., Mikoš, M., Serafin, J. (1986). Študija kompleksne vodnogospodarske ureditve za povodje Idrijce. 1. faza (Water Management Plan for the Idrijca River basin). Ljubljana: Vodnogospodarski inštitut, 80 p. (in Slovenian).

Zorn, M., Hrvatin, M. (2015). Škoda zaradi naravnih nesreč v Sloveniji med letoma 1991 in 2008 (Damage caused by natural disasters in Slovenia between 1991 and
2008). Ujma 29, 135-148 (in Slovenian with English abstract).

Zorn, M., Komac, B. (2008). Zemeljski plazovi v Sloveniji (Landslides in Slovenia). Ljubljana: Založba ZRC SAZU, Georitem 8, 159 p., https://doi.org/10.3986/9789612545505 (in Slovenian).

Zorn M, Komac B (2015) Naravne nesreče in družbena neodgovornost (Natural disasters and social irresponsibility). Geografski vestnik 87(2), 75-93, https://doi.org/10.3986/GV87205.

Zorn, M., Komac, B., Natek, K. (2009). Naravne nesreče kot omejitveni dejavnik razvoja (Natural disasters as a limiting development factor). In: Nared, J., Perko, D. (Eds.): Razvojni izzivi Slovenije. Ljubljana: Geografski inštitut Antona Melika. Regionalni razvoj 2, 135-145, https://omp.zrc-

sazu.si/zalozba/catalog/view/1009/4293/519-2.

Zorn, M., Komac, B., Pavšek, M., Pagon, P. (2010). Od razumevanja do upravljanja. Ljubljana: Založba ZRC SAZU, Naravne nesreče 1, 374 p., Available at: https://giam.zrc-sazu.si/sites/default/files/Naravnenesrece-01.pdf (9 February 2021).

Zorn, M., Komac, B., Ciglič, R., Pavšek, M. (2011). Nedogovorna odgovornost. Ljubljana: Založba ZRC SAZU, Naravne nesreče 2, 149 p, https://doi.org/10.3986/9789612545710.

Zorn, M., Komac, B., Kumelj, Š. (2012). Mass movement susceptibility maps in Slovenia: the current state. Geografski vestnik 84(1), 99-112. http://zgs.zrcsazu.si/Portals/8/Geografski_vestnik/vestnik-84-1-zornkomac-kumelj.pdf (28 September 2020).

Zorn, M., Komac, B., Ciglič, R., Pavšek, M. (2014). (Ne)prilagojeni. Ljubljana: Založba ZRC SAZU, Naravne nesreče $\mathbf{3}, \quad 273 \quad$ p., https://doi.org/10.3986/9789612546762.

Zorn, M., Komac, B., Ciglič, R., Tičar, J. (2017). Trajnostni razvoj mest in naravne nesreče. Naravne nesreče $\quad 4, \quad 192 \quad$ p., https://doi.org/10.3986/9789610502678.

Zorn, M., Komac, B., Ciglič, R., Logar, E. (2020). Domači odzivi na globalne izzive. Ljubljana: Založba ZRC SAZU, Naravne nesreče 5, 176 p., https://doi.org/10.3986/9789610502678.

ZUOPZP (2002). Zakon o ukrepih za odpravo posledic določenih zemeljskih plazov večjega obsega iz let 2000 in 2001 (Act on Measures to Repair the Damage Caused by Certain Large-Scale Landslides in 2000 and 2001). Official Gazette of the Republic of Slovenia 21, 592- 
Mikoš M.: After 2000 Stože Landslide: Part II - Development of landslide disaster risk reduction policy in Slovenia Po zemeljskem plazu Stože leta 2000: Del II - Razvoj politike zmanjševanja tveganja nesreč zaradi zemeljskih plazov v Sloveniji

Acta hydrotechnica 34/60 (2021), 39-59, Ljubljana

1600.

list.si/_pdf/2002/Ur/u2002021.pdf (1 February 2021).

ZUPSB (2000). Zakon o ukrepih za odpravo posledic plazu Stože v Občini Bovec in plazov večjega obsega, nastalih na območju Republike Slovenije po 15. oktobru 2000 (Act on the Measures to be Taken to Repair the Damage Caused by Landslide Stože in Bovec Municipality and by Large-Scale Landslides in the Territory of the Republic of Slovenia Occurring after 15 October 2000). Official Gazette of the Republic of Slovenia 124, 13700. $\quad$ https://www.uradnilist.si/_pdf/2000/Ur/u2000124.pdf (27 September 2020).
ZV-1 (2002). Zakon o vodah (Water Act). Official Gazzette of the Republic of Slovenia 67, 7648-7680. https://www.uradni-list.si/_pdf/2002/Ur/u2002067.pdf (in Slovenian).

ZV-1-NPB8 (2020). Zakon o vodah (ZV-1) - neuradno prečiščeno besedilo št. 8 (Water Act - unofficial consolidated version Nr. http://pisrs.si/Pis.web/pregledPredpisa?id=ZAKO1244 (in Slovenian) (28 September 2020).

ZVNDN-B (2010). Act on the Protection against Natural and Other Disasters - unofficial consolidated text, no. 5 (Zakon o varstvu pred naravnimi in drugimi nesrečami NPB5). Uradni list $R S \quad$ 97/10, http://www.sos112.si/slo/tdocs/zvndn_ang.pdf (in Slovenian). 